\title{
rasest \\ Biotech grows in Hong Kong
}

\section{Hong Kong}

SEVERAL Asian governments regard biotechnology as an obvious successor to consumer electronics in their struggle to succeed in the world's high-technology markets. The pursuit has plenty to recommend it to nations that are relatively poor and often short of land. After all, biotechnology is scientist-intensive - research and development accounts for about 80 per cent of overall costs - and it does not require huge amounts of capital or working space.

For several years, Japan has played a small but significant role in the global biotechnology business. More recently, the governments of Singapore and Taiwan have taken measures to encourage the growth of the biotechnology industries. Singapore has set up an Institute of Molecular Biology to undertake basic research and biotechnology, while Taiwan has funnelled several million US dollars into biotechnology-related industries such as agriculture and pharmaceuticals.

But the first effective biotechnological products to emerge from Asia that are not Japanese may well come from Hong Kong, the laissez-faire British territory that is due to revert to China in 1997.

Three years ago, a small group of scientists founded the Hong Kong Institute of Biotechnology (HKIB). A year later, the non-profit institute received $\$ 22$ million in funding from the Royal Hong Kong Jockey Club. This year, HKIB has started to produce results - a joint venture with the US pharmaceutical company Syntex that will search for new pharmaceutical products, and a memorandum of understanding with Radian, another US company, for a venture that will offer environmental technology services to local companies.

The leaders of HKIB share a strong international outlook. Dominic Lam, the 43-year-old institute director, has an array of academic titles in the Houston area, including director of the Baylor College of Medicine's Center for Biotechnology and adjunct professor of neurobiology and anatomy at the University of Texas Health Science Center, and he owns or partly owns five biotechnology-based companies around Houston.

HKIB's associate director, Siu-Leung Lee, has a similarly broad background. With a bachelor's degree in biology from the Chinese University of Hong Kong and a $\mathrm{PhD}$ in biochemistry from Purdue University in the United States, Lee has held academic posts at Yale and Texas A\&M Universities. In 1982, he went into industry, leading a research group at Corning Glass Works, and two years later moved to Battelle Memorial Institute to set up a bioseparations laboratory. He returned to a full-time job at HKIB in 1989.
A major reason for the founding of the HKIB was the prospect that it would serve as a gateway to mainland China, which has both vast resources of natural products and a large reservoir of excellent biotechnologists. Indeed, Lam characterizes China as the sleeping giant of the Asian biotechnology business. "China offers more of an opportunity in developing biotechnological products than anyone else in the world, including the US," he said.

Even the current political climate has not dimmed that prospect, he said. "To a large extent, the good people in biotechnology move up, and they have a fairly decent peer review system."

HKIB's joint venture with Syntex, called HKIB/Syntex, will use Chinese resources in its first project. The objective is to screen synthetic and natural products from China - particularly those used in traditional Chinese medicine - for pharmaceutical potential. Scientists at HKIB and Syntex Research in Palo Alto, California, will carry out the screening. The raw materials will be gathered by researchers associated with the Chinese Academy of Sciences.

HKIB is also acting as the middleman in a more local project, designed to clear indigo dye from Hong Kong's waterways. The territory's garment industry uses about 4,000 tons of dye annually, to make blue jeans blue. According to Chinese University microbiologist Kai Keung Mark, about one-tenth of that ends up in the waterways, which it stains an unpleasant blue/black colour.

Two years ago, Mark discovered a natural strain of bacteria that degrades indigo, converting it into colourless, nontoxic compounds. Now, Mark and HKIB are undertaking research on the compound. Investigations include determining how much the bacteria produce of the enzyme responsible for decolourizing indigo and analysing how long the bugs can withstand high concentrations of indigo in waste water from garment factories. Biologists hope that genetically engineered versions of the bacteria could replace the process of stone washing to give jeans the fashionably faded look, and could even remove the indigo from waste waters before they reach waterways.

HKIB's other main initiative, in cooperation with the US company Radian, shows the institution's pragmatic side. The aim is to provide clean-up services, such as water treatment, for Hong Kong companies, and the joint venture will not restrict itself to biotechnology-based services. It is prepared to offer whatever technology is needed for the jobs at hand. "We're problem oriented, not technology-oriented", explained Lee.

Peter Gwynne
Science park in Macao

\section{Hong Kong}

THE government of Macao, the Portuguese colony across the Pearl River estuary from Hong Kong, plans to establish a new science and technology park with help from a newly formed Sino-Singaporean joint venture. The park, which will cost several hundred thousand US dollars, will be built on 3.4 million square feet of reclaimed land on the Macao island of Taipa.

Macao normally lives in the shadow of Hong Kong, but this year the Portuguese enclave has made technological headlines of its own. In March, the United Nations University opened its International Institute for Software Technology in Macao. The object of the institute is to help research, development and advanced training needs of developing countries. The new science park is a further indication of the colony's commitment to technology.

Details of the park have not yet been released. However, Long Zhu Science and Technology Company, the SinoSingaporean joint venture helping to finance the park, has said it will use China's technological capabilities to foster the growth of the park. Macao is due to revert to China in 1999, two years after Hong Kong. P.G.

\section{Hong Kong university}

\section{Hong Kong}

A NEW science-directed university will open its doors in Hong Kong in October. The Hong Kong University of Science and Technology will join two other universities and two polytechnics that offer scientific training in this British territory of six million people.

Establishment of the university, which was officially approved in 1988 after several years of debate, is a response to concern that Hong Kong is falling behind other Asian nations in its development of technology. Close to 80 per cent of the territory's electronic companies have fewer than 50 employees, and so cannot afford to carry out research on new products. Meanwhile, countries such as Malaysia and Thailand are undercutting Hong Kong's traditional advantage of cheap labour for assembly of high-technology products. Hong Kong's government has for many years taken a laissez-faire attitude to industrial policy. But recently it has recognized the need to support industry indirectly, by providing high-quality higher education in science and technology.

The new university expects to open its doors to 700 students, including 560 graduate students. It will have more than a hundred faculty members in departments of biochemistry, biology, chemistry, computer science, electrical and electronic engineering, mathematics, mechanical engineering and physics. 